\title{
ASPECT OF LANGUAGE FOREIGN EDUCATION IN PELANGI MELBOURNE BY ZUHAIRI MISRAWI (Structural Semiotic Study)
}

\author{
Rahmat Basuki \\ Nahdlatul Ulama Lampung University \\ rahmatbasuki85@yahoo.co.id
}

\begin{abstract}
The reserach aims is identify and understand thoroughly foreign language education contained in Pelangi Melbourne Novel by Zahairi Misrawi. The research is qualitative Approach with analysis methode uses a structural study semiotic. The sourche of data is a Pelangi Melbourne Novel. The Data collected by reading over to understand and obtain data of foreign language education foreigners the factor personal and sociocultural factors withsemiotic structural study Methode. So, The data are grupp suitable foreigh learning theory. After that, Tha analyzing and doing interpretation is based on the theory foreign language learning.The researchers finded personal and social factors culture in Semiotic structural Study data are : form of icons $42(36 \%)$ index of $58(52 \%)$ and the symbol of $10(13 \%)$. Third The semiotic is provide interpretation about foreign language education contained in the novel. Based on Pelangi Melbourne Novel, The Story gives an explanation that language education is not only requires learning English, but need the living environment and learning support. Personal, Allstudents must have believed that selfnature both within the class and outside the classroom so that he is ready to communicate, eliminating anxiety and so forth. In addition, educational institutions must also be provide student residence so it is easy and convenient for students practice the English language without Indonesian rule out as national language.
\end{abstract}

Keywords: foreign language; education; personal factor, social and cultural factors, structural semiotic

\section{INTRODUTION}

The Literature is a product of culture, both the future life and the past. Talking about literature means talking about the sensitivity of feelings to social reality in society. The last 10 years, Novel Literary rapid development is a novel. Novel Laskar Pelangi (2005), When Cinta Bertasbih (2007), Country 5 Tower (2009) or other popular novels. This condition proves that the novel is very in gandrungi novel readers. No less fun, the novels are the works of Indonesian writers.

As a social critique or a work of culture, Novels can be analyzed from various perspectives and dimensions of life. In addition to the majority idea, the novel also has a minority idea. Although as a supporter, not a few people analyze the idea of minorities for certain purposes, such as understanding the culture of society, personal characters and other stories. That is, literary works can be analyzed from various aspects.

The One novel that can be seen from the aspect of language education is Novel Pelangi Melbourne. This novel was developed based on the author's personal experience while participating in an English short course fellowship program in Australia. Although most people rate this novel from the side of different religious marriage controversy. 


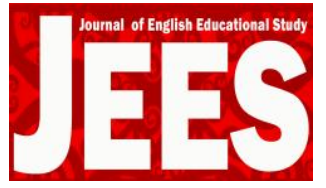

Journal of English Educational Study

Volume 2 Issue 2 November 2019 Page 70-77

E-ISSN: 2655-0776

The novel Pelangi Melbourne examples of literary works are able to provide a complete and thorough picture when drawn in scientific science. The novel story has intrinsic elements as a plot of the story as well as raises social problems. Content the Melbourne Pelangi novel, the authors present the problems faced by foreign language learners while living in other people's countries and the social problems it faces.

According to Brown's theory in foreign language learning, there are theories about personal factors and socio-cultural factors in learning a foreign language. From a growing story, the problems of learning a foreign language in accordance with the problem of learning theory presented by Brown in the book Learning and Language Teaching.

In Indonesia, Learning a foreign language is required to address global challenges as English as the language of international communication. In the language education curriculum, English is one of the languages included in the subjects, in addition to Mandarin, Arabic and French.

In learning foreign languages, according to Dauglas Brown (2007: 155) among which need to be considered is the personal factors and socio-cultural factors of learners and place of learning a foreign language. Based on his theory, personal factors are divided into affective and motivational spheres. 1). Affective domains include Harkat, Attribution and Self-Reliance Theory, communication willingness, barriers, risk taking, anxiety, Empathy as well as extrovet and Introvet. 2) motivation consists of intrinsic and extrinsic motivation and integrative and instrumental orientation. Selanjutany are socio-cultural factors, according to Brown, sociocultural factors consist of, Culture, Stereiotype or Generalization, Attitude, Language acquisition, social distance and the last policy and politics of language.

The above theory explains that the affective domain that is part of psychology is a picture of personal readiness with all the conditions that are in the learning. In addition, the sociocultural factors will give an idea that the environment will have a major impact on the success of the success of foreign language learning.

The Artikel $\mathrm{h}$ is conducted to provide an overview of the messages in the literary work in the form of a novel about the learning of foreign languages from personal factors and sociocultural factors.

\section{METHOD}

The research is a qualitative research with content analysis technique. According to Nyoman Kuntha (2010: 48) method of analysis The content in content analysis method consists of 2 kinds, namely latent content and communication content. The latent content is the content contained in documents and manuscripts, while the content of the communication is the 
message contained by the communication that occurs. While semiotic study of structural according to Syuropati and Agustina (2012: 72): Peirce divides three types of signs based on the relationship between the sign with the signified, namely: (1) Icon, a sign that has similarities with the meaning (2) index, a sign containing a causal relationship with what is indicated, (3) symbols, Signs that have a meaning relationship with the signified in accordance with certain social conventions.

The object of this literary research is the novel Pelangi Melbourne by Zuhairi Misrawi. The data analyzed include the reading in detail in the form of words, sentences and phrases contained in the novel. Those step, the data are grouped according to foreign language learning theory and analyzed. The data needed in the analysis are novel intrinsic elements and foreign language learning both personal factors and socio-cultural factors based on the theory of Dauglas Brown.

The Data data are then grouped based on semiotic structural theory consisting of icons, indexes and symbols as well as Pearce's theory. The data are then interpreted based on meaning and general description based on foreign language learning.

\section{FINDING AND DISCUSSION}

Based on the analysis that has been done, researchers found novel intrinsic element as novel generally. The elements are themes, elements, figures and characterizations. The analisys of data, researchers found that the viewpoint used by the author is the corner of a third person, with the mention of the main character.

As for foreign language learning, researchers find words, phrases and phrases that can be interpreted as part of personal factors in the Pelangi Melbourne novel as the following

Table 1

Personal Factor in Foreign Langauge Education

\begin{tabular}{|c|l|c|}
\hline No & \multicolumn{1}{|c|}{ Personal Factors } & Total \\
\hline 1 & Prestige & 4 \\
\hline 2 & Attribution Theory and Eligibility & 4 \\
\hline 3 & Communication & 9 \\
\hline 4 & Obstacles & 5 \\
\hline 5 & Risk Taking & 8 \\
\hline 6 & Worry & 7 \\
\hline 7 & Empaty & 7 \\
\hline 8 & Ekstrovet and Instrovet & 17 \\
\hline 9 & IntrinsicandEkstrinsic Motivation & 5 \\
\hline 10 & Integratifand Instrumental Orientation & 10 \\
\hline
\end{tabular}


The table above explains if Brown's theory in foreign language learning about sociocultural factors actually has a dominant role. Factors of interest of social status, self-worth gives the assumption that everyone is interested in learning a foreign language. Communication willingness, risk taking, obstacles, anxiety and empathy are qualities that can arise out of confidence and a strong desire so that everyone is willing and able to perform kewajibannnya in learning the language.

The introvert and extrovert nature of foreign language learners illustrates that the importance of open and open communication to be active and dominant in communication will be so helpful that everyone is "compelled" to learn the language as soon as possible.

Table 2

Socio-Culture Factor of Foreigh Language Education

\begin{tabular}{|c|l|c|}
\hline No & \multicolumn{1}{|c|}{ Social-Culture Factors } & Total \\
\hline 1 & Culture & 7 \\
\hline 2 & Stereotype and Generalization & 8 \\
\hline 3 & Attitude & 7 \\
\hline 4 & Language Acquisition & 8 \\
\hline 5 & Social Distance & 2 \\
\hline 6 & Politics and Language Policy & 7 \\
\hline
\end{tabular}

This socio-cultural factor occurs as a result of the different social cultures of the community in which to study a foreign language with the origin of a foreign language student. This happens because the language being studied is a foreign language or we learn a language abroad. Culture, social distance and attitudes are a general description of how many cultural differences occur that can not be imposed or ignored.

Culture, one of its products is language. The social distance that occurs between the student and the other student or the learner with the environment gives the equivalent of different problems. Differences that have to be adjusted but sometimes that must be maintained as a personal identity. In principle, the differences can be in siasati so it does not affect the learning of foreign languages.

The data were analyzed in a semiotic study with Pearce theory consisting of icons, indexes and symbols. Based on this study, each data in a sentence is described in detail in accordance with the theory of personal factors and socio-cultural factors to make it easier to understand. 
Table 3

Data Clasification of StructuralSemiotic Data

\begin{tabular}{|c|c|c|}
\hline No & StructuralSemiotic & Total \\
\hline 1 & Icon & 42 \\
\hline 2 & Indeks & 58 \\
\hline 3 & Symbol & 10 \\
\hline & Total & $\mathbf{1 1 3}$ \\
\hline
\end{tabular}

TheLiterature is a unique science and able to be present wherever literature is often juxtaposed with the science of language. As a language product, literature can be analyzed from various angles and approaches, for example structural semiotic. The blend of language theory and novel literary work will help everyone to understand the message and in the literary work.

The data in the form of words, sentences and phrases provide a clear picture to gain an understanding of foreign language learning in the form of personal factors and socio-cultural factors. Both of these factors greatly affect the learning process will succeed or not.

In language learning, everyone has their own weaknesses and strengths, both personally and at the background of participating countries. These cultures should be adapted to the social setting of the society in which they learn a foreign language so that they will be able to learn the language in total and be able to apply it in everyday life.

The data included in the icon classification describes the cultural identity and personal character that occurs in language learning. The icons in the Pelangi Melbourne novel provide an overview of Melbourne's situational and its effects on the learning process of foreign languages. Icon also explains that everyone has the character and culture of each country has an identity that can not be equated or differentiated. For example a quote on page 79:

'Berbeda dengan Zaki yang kemana-kemana masih membawa kamus, menjagajaga jika kekurangan amunisi kosakata.'

The kamus is an icon representation. This object describes the dictionary as the source of the language vocabulary. For foreign language learners, dictionary is the identity of the desire can master the vocabulary as much as possible. The more the vocabulary that the student learns the smaller the student depends on the dictionary. This confirms if the dictionary has an important role in learning a foreign language.

Next example is sentences in page 331 :

'Besok pagi adalah jadwa lia mengikuti IELTS (International English Leanguage

Testing System).

IELTS is one of the icon representations. This representation can be interpreted that each country has a different standard of foreign language assessment between one country and another. The IELTS is the basic English proficiency assessment standard applicable in 
Australia. In English, the basic ability standard other than IELTS is TOEFL. If IELTS applies to in some European countries and Australia whereas TOEFL applies to USA.

Furthermore, The kind of semiotic is Index. This element in semiotics explains causality. In this study, causation explains the problems that occur between several storytellers, whether psychological, cultural, or other issues. Example quote as in page 76 of the Pelangi Melbourne novel.

'melainkan ia mempunyai alasan lain yang lebih prinsipil: ia ingin membiasakan diri bercakap dengan bahasa Inggris, bukan dengan bahasa Arab.'

The object of membiasakan diri used to is the index representateman. The object of getting used to is to explain if previous students have not used English in daily communion. this representatment can be interpreted as an effort so that learners can master the English language quickly by practicing it in everyday life. that way, they will get used to using it in a conversation of all activities

The next sentences is page 138 :

'Semua pelajar harus mempunyai keberanian dan kesempatan yang sama untuk menyampaikan pendapatnya dalam bahasa Inggris. Dalam meningkatkan kemampuan berbahasa Inggris, satu aspek yang niscaya dimiliki oleh seorang pelajar adalah keberanian untuk berbicara.'

The above quote describes the cause as a representation of the index. This object explains all the limitations of foreign language learners, they must have the courage and opportunity with the conditions that exist in the language learning environment. This trait will provide an explanation that learning a foreign language is an opportunity that must be utilized maximally so that the learning process will work as expected.

The next kind semiotic is the symbol. The symbols depict the identity of meaning according to the agreement in force in society. Here is a quote on page 123 as one of the symbols found in the Melbourne Pelangi novel.

'Dalam belajar bahasa Inggris yang paling penting adalah mental. Bahasa tidak bisa disimpan dalam hati. Bahasa harus diungkapkan melalui lisan. Dan itu butuh mental baja dan keberanian.'

The mental and mental baja are representations of symbols. This object explains the psychological power of foreign language learners with the conditions occurring in the learning environment and the limitations of the learner. With a mental readiness, students are ready to face everything in the process of learning a foreign language. 


\section{CONCLUSION}

Based on the results of research that has been done aspects of foreign language education contained in the novel Pelangi Melbourne. The novel intrinsic structure of the theme, character, plot, background and point of view have a relationship that is a unity and intertwined alignment that makes the story that runs to be developed and interesting to read.

Aspects Foreign language education in the form of personal factors contained in Melbourne Pelangi novel consists of affective and motivational spheres. Affective domain consists of Harkat, Attribution and Self-Reliance Theory, Communication Willingness, Barriers, Risk Taking, Anxiety, Empathy and Extrovets and Introvet. The motivation consists of intrinsic motivation and extrinsic motivation as well as instrumental orientation and integrative orientation.

Aspects of foreign language education in the form of socio-cultural factors comprised of culture, stereotypes or generalizations, attitudes, language acquisition, Social Distance and Policy and Political Languages

English language education requires the involvement of many parties. For students, the need for adult nature and great confidence to succeed. In addition, students must also be prepared with all the existing conditions such as shock culture, feel alienated and so forth.

\section{REFERENCES}

Arif Rohman, Memahami pendididikan dan IlmuPendidikan, Laskbang Mediatama, Yogyakarta 2009.

Brown. H. Dauglas, Prinsip Pembelajaran dan Pengajaran Bahasa,Jakarta: Pearson Education, Inc, 2004

Chaer. Abdul, Psikolinguistik Pendekatan Teoritik,Penerbit Renika Cipta, Jakarta. 2009.

Djaali, PsikologiPendidikan, Bumi Aksara, Jakarta, 2009

Endraswara, Suwardi, Metodologi Penelitian Sastra Epistemologi, Model, Teori dan Aplikasi. Yogyakarta. Caps, 2011

Eagletion, Terry; Literarry Theory, An. Intrudition, University Of Minnesota Press, Minneapolis, 1983.

Jabrohim (Editor), Teori Penelitian Sastra, Yogyakarta, Pustaka, 2012

Kosasih, E. Dasar-Dasar Keterampilan Bersastra. CV. YRAMA WIDYA, Bandung, 2012, 61

KunthaRatna,Nyoman. Metodologi Penelitian Kajian Budaya dan Ilmu Sosial Humaniora pada Umumnya. Yogyakarta. Pustaka Pelajar. 2010

Kramsch, Claire; Language and Culture, Oxford University Press. London. 2008 
Journal of English Educational Study

Volume 2 Issue 2 November 2019 Page 70-77

E-ISSN: 2655-0776

Luxemburg, Jan Van, Miekel Baldan Willem G. Westeijn.Pengantar Ilmu Sastra. Jakarta. Gramedia, 1984

Moleong, Lexi J. Metodologi Penelitian Kualitatif Edisi Revisi, PT. Remaja Rosdakarya, Bandung, 2010

Moh. A. Syuropatidan Agustina A. 7 Teori Sastra Kontemporerdan 17 Tokohnya. IN AzNA Books, Yogyakarta, 2012

Marriannecelce-Murcia, Teaching English as a second or Foreign Language.Thomshon Learning, Singapure

Nurgiyantoro, Burhan. Teori Pengkajian Fiksi. Yogyakarta. GadjahMada University Press, 2009.

Nyoman Kuntha Ratna, Teori, Metode, danTeknik Penelitian Sastra, Pustaka Pelajar, Yogyakarta, 2007

Phytian, B.A Bahasa Inggris Yang Baik dan Benar, Kesaint Blanc, Jakarta, 2005.

Slamet, Santoso, Teori-Teori Psikologi Sosial, PT. RafikaAditama, Bandung, 2010

Staton, Robert. Teori Fiksi. TerjemahanSugihastuti. Yogyakarta: PustakaPelajar

Semi, M Atar.Metode Penelitian Sastra. Bandung. Angkasa. 1993

Sumardjo, Jacob danSaini K.M. Apresiasi Kesusastraan. Jakarta. Gramedia, 2008

Teeuw, A. Sastra dan Ilmu Sastra, Pengantar Teori Sastra. Jakarta. Pustaka Jaya. 1984

Wolfolk. Anita Educational Psychology Active Learning Edition, PustakaPelajar, Yogyakarta, 2010 